\title{
Three approaches to labor-market vulnerability and political preferences
}

\author{
Paul Marx ${ }^{1}$ and Georg Picot ${ }^{2 \star}$ (D) \\ ${ }^{1}$ Institute for Socio-Economics, University of Duisburg-Essen, Duisburg, Germany and ${ }^{2}$ Department of Comparative Politics, \\ University of Bergen, Bergen, Norway \\ *Corresponding author. E-mail: georg.picot@uib.no
}

(Received 5 June 2018; accepted 15 June 2018; first published online 12 November 2019)

\begin{abstract}
This contribution starts by presenting the three main approaches that political scientists use to analyze labor market vulnerability. We proceed to discuss various operationalizations of labor market vulnerability. We examine how they relate to the three theoretical approaches and we evaluate the consistency between theory and measurement. Finally, we recommend three measures that political scientists should deploy when analyzing the effect of labor market vulnerability on political preferences. We point out what each of these variables captures and what methodological challenges should be taken into account when using them.
\end{abstract}

Keywords: Comparative Political Economy; Comparative Politics: Industrialized Countries; Comparative Politics: Political Behavior; Political Economy

The post-industrial transformation of labor markets and its political consequences are becoming a major topic in political science. One emerging strand of research deals with how labor market vulnerability affects policy and party preferences (see symposium introduction). In this contribution we, first, provide an overview over different conceptual approaches to studying labor market vulnerability and political preferences. ${ }^{1}$ We then discuss what must appear to the uninitiated as a confusing variety of vulnerability operationalizations. This discussion complements Vlandas's (2018) empirical contribution to this issue. Finally, we recommend vulnerability measures for use in preference research based on two criteria: coherence with theory and ease of interpretation. In doing so, we hope to make it easier for non-specialist political scientists to include labor market vulnerability in their research.

\section{Three approaches}

With some simplification, the literature on labor market vulnerability and political preferences clusters in three groups. First, the individual-risk approach focuses on job characteristics that influence preferences through economic self-interest. Analogously to low income, unemployment risk leads individuals to support social protection and political parties that promise it, typically left-wing parties. The argument has been applied inter alia to exposure to globalization (Walter 2010; Walter 2017) and occupational unemployment (Rehm 2009) and assumes individualistic and economically instrumental decision makers. Risk is usually conceptualized as a continuum and as varying in degree across individuals.

\footnotetext{
${ }^{1}$ We focus on characteristics of vulnerable jobs rather than socio-structural antecedents of vulnerability (such as education, age, gender, or ethnicity).

(c) The European Political Science Association 2019.
} 
Second, insider-outsider theory is also based on the nexus between objective risk, self-interest, and policy demand. It adds the notion that risk is distributed discontinuously as a result of labor market institutions. In particular, dismissal regulation creates two segments: "Insiders" have regular employment contracts and are relatively insulated from unemployment. "Outsiders" cannot find jobs or have non-standard jobs with higher unemployment risk. Thus, distinct legal categories of employment contracts create a discontinuous distribution of risk. Accordingly, insider-outsider theory deviates from a purely individualistic decision logic and incorporates an organizational argument. Insiders benefit as a group from their organization in unions and from ties to social democratic parties. Outsiders are a diffuse group lacking effective representation. These group-level divisions stand in contrast to traditional partisan theory, which regards labor as a unitary actor (Rueda 2007).

Third, sociologists and psychologists stress the subjectivity of labor market vulnerability. This approach diverges from rationalist political-economy premises. It highlights that "two employees in the same situation can experience differing degrees of job insecurity because they will perceive and interpret the situation differently" (Sverke, Hellgren and Näswall 2002, 243). The perspective has conceptual advantages. It acknowledges that those who seem institutionally well protected may actually perceive their situation as insecure. After all, insecurity can also stem from macroeconomic, company-specific, or personal factors; all of which are reflected in subjective assessments. Moreover, the subjective approach facilitates a more nuanced conceptualization of risk, e.g., distinguishing between cognitive and affective insecurity (Anderson and Pontusson 2007) and between worries about job loss and worries about re-employment (Marx 2014). It thereby lends itself to a more explicit theorization of labor market risks and psychological mechanisms. How objective risk factors translate into subjective worries should, for instance, depend on information about the job market and personality traits. Finally, subjective measures provide a parsimonious way to take into account sources of (in)security at the household level. Despite these advantages, subjective insecurity is rarely used to explain political preferences (but see Hacker, Rehm and Schlesinger 2013).

\section{Operationalizations and pitfalls}

The individual-risk concept is typically captured by merging individual with occupational or sectoral information. For instance, the extent to which a job is "offshorable" is used to measure the risks workers face in specific occupations (Walter 2017). Similarly, the level of unemployment in an occupation indicates risks for workers employed in it. Interestingly then, the individual-risk approach tends to rely on aggregated data. This creates a certain risk of committing ecological fallacies. In addition, these operationalizations rely on statistical accounting categories (e.g., International Standard Classification of Occupations) that have been created independently of the research question at hand. Consequently, researchers need to make sure that these categories are sensible for their theoretical purpose. They also need an argument why the specific context (e.g., occupation) matters regardless of the individual work situation. For occupational unemployment (Rehm 2009), the case can be made that job markets are differentiated by occupation and that the market situation affects risks of both employed and unemployed workers in that occupation. At the same time, occupational or sectoral risk measures are relatively transparent and intuitive. They are easy to compute and, owing to standardized classifications, comparable for most industrialized countries. Finally, the operationalizations yield continuous indicators and therefore correspond to the theoretical view that risk varies by degree.

The picture becomes more complex when we move to insider-outsider theory. Initially, insider-outsider operationalizations were based on labor market status. Following Rueda (2007), outsiders often comprise the unemployed and non-standard workers (without full-time 
permanent contracts). ${ }^{2}$ Others have argued that this composite operationalization disguises important differences (Emmenegger 2009; Marx and Picot 2013). As a result, different labor market situations such as unemployment, part-time work, or temporary contracts are measured by separate dummy variables (e.g., Burgoon and Dekker 2010; Gelepithis and Jeannet 2018). Recently the approach has been extended to precarious self-employment (Jansen 2016). Because several studies have indeed uncovered substantial differences between different "outsider" situations, there are strong empirical reasons for the differentiated over the composite approach.

Operationalizations based on labor market status correspond directly to the theoretical substance of insider-outsider theory: risk is distributed discontinuously because legally defined labor market segments are divided by mobility barriers. Moreover, the differentiated operationalization is intuitive, transparent, and easy to implement (provided data sets include appropriate variables). Nevertheless, there are three caveats. First, labor market status is an individual characteristic whereas workers in reality often share resources in households. Second, an individual's current employment contract disregards that she may expect to proceed to a different, possibly better, labor market status in the near future. Third, labor market status might conceal heterogeneity in more important characteristics (such as age, gender, occupation, or education).

Motivated by these limitations, Schwander and Häusermann (2013) have developed an alternative insider-outsider operationalization. They examine labor market situations in groups defined through the intersection of post-industrial social classes, gender, and (dichotomized) age. The difference between the group-specific and the total-workforce rate of non-standard employment and unemployment then yields a group-specific continuous measure of "outsiderness," used as an individual-level variable. Because of the complexity of this operationalization and because it has been adopted by other researchers, it merits a closer look.

If insider-outsider divides are seen as a new base for class politics (as some have suggested), rather than merely one type of labor market vulnerability, this approach brings theoretical advantages. It identifies demographically homogenous groups that are collectively disadvantaged. However, in our view, these advantages come at considerable costs. To begin with, this operationalization implicitly draws on at least three theoretical frameworks: post-industrial class, insideroutsider divides, and individual risk. This theoretical ambiguity creates three problems. First, the basic indicators the operationalization is based on (post-industrial class, gender, and age) have all been used as independent explanations of political preferences. Hence, the composite indicator is likely to pick up other influences than labor market vulnerability. Second, insider-outsider divides can run through occupational groups. Rising occupational unemployment might increase the vulnerability of all members of an occupation as general demand for an occupation declines. Yet, in case of strict dismissal protection, the risk of temporary workers in that occupation is much higher than the risk of those on permanent contracts. Indeed, a high share of temporary workers reduces the risk of the others. This is because employers achieve employment flexibility through hiring non-standard workers, which (at least in the short term) reduces flexibility pressure on standard workers. Hence, the outsiderness indicator risks categorizing workers who may well be highly protected insiders as outsiders if they work in an occupation with many non-standard workers. Third, by adopting a continuous measure that varies across a wide span of differently composed groups the indicator assimilates the individual-risk approach in spite of being originally motivated by insider-outsider theory. It uses group-specific unemployment and nonstandard employment rates similarly to Rehm's (2009) occupational unemployment rate. For this reason, Vlandas (2018) subsumes Schwander and Häusermann (2013) under the occupational unemployment approach in spite of their reference to insider-outsider theory. This raises two questions: Does the operationalization still speak to insider-outsider theory with its emphasis on institutionally defined labor market segments? And does it produce an empirical value-added compared to simpler individual-risk measures such as occupational unemployment rates? In any

\footnotetext{
${ }^{2}$ Rueda included only involuntary temporary or part-time contracts, but this distinction is often omitted.
} 
case, 'Schwander-Häusermann outsiders' are different people than 'Rueda outsiders' and they have different political preferences (Rovny and Rovny 2017).

By contrast, labor market status is close to the original notion of insider-outsider divides and operationalizes it in a transparent way. We therefore see it as preferable, but acknowledge its limitations. Households do matter, but can be accounted for with appropriate data (e.g., Marx and Picot 2013). Demographic heterogeneity within a certain labor market status can be controlled for statistically. That said, we fully share the agnosticism whether labor market status alone serves as a new class base. The most important shortcoming, in our view, is that it cannot account for heterogeneity in employment prospects. This can be remedied by using additional variables-either based on individuals' subjective mobility prospects (Marx 2015) or occupational information (Vlandas 2018). Another aspect to keep in mind is that implications of labor market status vary by institutional context. For example, what it means to be unemployed depends critically on passive and active labor market policy; and how well-protected open-ended contracts really are depends on the regulation of dismissals. Analyses of labor market status should therefore remain context-sensitive, whether this is done more coarsely through multi-level analysis or through embedding micro-analysis in (comparative) case studies (e.g., Lindvall and Rueda 2014; Marx and Picot 2014). More generally, institutional context should influence decisions on which vulnerability measure is relevant. Temporary employment, for instance, matters less in the United States (Gelepithis and Jeannet 2018), but cannot be neglected in Continental and Southern Europe (Marx 2015).

The third approach uses survey respondents' self-placement on subjective-insecurity scales. Typically, this means (dis)agreement with statements such as "My job is secure" (cognitive [in-]security) or answers to questions such as "Do you worry about the possibility of losing your job?" (affective insecurity). As mentioned, the major advantage of subjective measures is that they reflect all relevant sources of job insecurity. Even if risk perceptions are inaccurate they should matter for political preferences. Hence, compared to socio-structural measures, they are closer to political preferences in the causal chain. Considering these clear advantages and the fact that subjective insecurity is widely studied in sociology and psychology, it is surprising that it is not more commonly considered in political-preference research. Also in this symposium it is conspicuously absent. An important and well-justified criticism when political views are regressed on subjective economic perceptions is the possible endogeneity of both variables to an overall set of political commitments. It is, for instance, plausible that insecurity stems from perceptions of the macro-economy that are biased through party identification, which, in turn, correlates with political preferences. As a result, insecurity-preference correlations could be artificially inflated. Similar concerns have led to intense debates in economic-voting research (see Marx 2014 for a discussion). Promising ways to tackle this problem are the use of panel data and experimental studies. In addition, it can be a good starting point to assess empirically the extent of the problem. In one study (Marx 2014), the insecurity-preference correlation did not change substantively when respondents with strong party identification or left-right ideology were removed from the sample.

\section{Recommendations}

Researchers who want to include labor market vulnerability in their analysis of political preferences can draw on three different approaches. With due attention to theoretically consistent and transparent operationalization, the three approaches can complement each other. We regard the following three indicators (one from each approach) as most useful: occupational unemployment rates, labor market status, and subjective job insecurity.

Occupational unemployment is a theoretically convincing measure as it captures the balance of supply and demand for a certain skill set. It addresses not only the risk of losing a job but also difficulties in finding one. What it does not capture is insider-outsider divides within 
occupations. This is where labor market status comes in. It accounts for formal distinctions in the labor market: having employment or not as well as different types of employment contract. Together, the two measures, occupational unemployment rate and labor market status, go a long way in capturing the objective labor market situation of an individual: the general market forces for her skill set and her starting point in facing those market forces. It is reasonable to expect that both factors will influence political preferences by themselves. In addition, it is likely that occupational unemployment will affect individuals differently depending on their labor market status, which suggests studying interaction effects of the two (Vlandas 2018). When selecting measures and when interpreting results, it is important to account for the institutional context. This applies especially to labor market status.

We recommend subjective job insecurity for studying the psychological mechanisms that translate "objective" vulnerability into political preferences. Although subjective insecurity can be theorized as an independent variable on political preferences, the problem of endogeneity is not easily resolved in observational research. Therefore, we suggest three ways to use subjective indicators: first, as a direct explanatory variable if the reasons for insecurity are secondary and if suitable methods are available to reduce unobserved heterogeneity. This could be reached through relying on intra-personal variation over time (Margalit 2013) or through priming insecurity experimentally (Levine 2015). Second, subjective insecurity can be studied as an intermediate outcome. If the effect of objective measures on preferences is mediated by subjective risk perception, this makes the underlying theory more plausible (Walter 2010). Conversely, including the link between objective and subjective insecurity would be a good starting point to explore in which contexts labor market status produces only weak effects on preferences (e.g., because insiders become insecure). Third, subjective measures, such as self-assessment of employment prospects, can be used as a moderator of labor market status. This takes into account that outsiders (by labor market status) can have contrasting career expectations (Marx 2015). Subjective measures hence can help distinguish de jure and de facto outsiders in a parsimonious way. Of course, this approach is vulnerable to the same endogeneity concerns discussed above. It therefore is helpful to complement it with longitudinal data on observed employment trajectories (Emmenegger, Marx and Schraff 2015).

Acknowledgments. Paul Marx's research was supported by the North Rhine-Westphalian Ministry of Culture and Science through funding of the research project "The influence of socio-economic problems on political integration."

\section{References}

Anderson CJ and Pontusson J (2007) Workers, Worries and Welfare States: Social Protection and Job Insecurity in 15 OECD Countries. European Journal of Political Research 46, 211-235.

Burgoon B and Dekker F (2010) Flexible Employment, Economic Insecurity and Social Policy Preferences in Europe. Journal of European Social Policy 20, 126-141.

Emmenegger P (2009) Barriers to Entry: Insider/Outsider Politics and the Political Determinants of Job Security Regulations. Journal of European Social Policy 19, 131-146.

Emmenegger P, Marx P and Schraff D (2015) Labour Market Disadvantage, Political Orientations and Voting: How Adverse Labour Market Experiences Translate Into Electoral Behaviour. Socio-Economic Review 13, 189-213.

Gelepithis M and Jeannet A-M. (2018) The Political Consequences of Outsider Labour Market Status in the United States: A Micro-Level Study. Social Policy \& Administration 52, 1019-1042.

Hacker JS, Rehm P and Schlesinger M (2013) The Insecure American: Economic Experiences, Financial Worries, and Policy Attitudes. Perspectives on Politics 11, 23-49.

Jansen G (2016) Self-Employment as Atypical or Autonomous Work: Diverging Effects on Political Orientations. Socio-Economic Review: https://doi.org/10.1093/ser/mww017

Levine AS (2015) American Insecurity: Why Our Economic Fears Lead to Political Inaction. Princeton, NJ: Princeton University Press.

Lindvall J and Rueda D (2014) The Insider-Outsider Dilemma. British Journal of Political Science 44, 460-475.

Margalit Y (2013) Explaining Social Policy Preferences: Evidence from the Great Recession. American Political Science Review 107, 80-103. 
Marx P (2014) The Effect of Job Insecurity and Employability on Preferences for Redistribution in Western Europe. Journal of European Social Policy 24, 351-366.

Marx P (2015) The Political Behaviour of Temporary Workers. Basingstoke: Palgrave Macmillan.

Marx P and Picot G (2013) The Party Preferences of Atypical Workers in Germany. Journal of European Social Policy 23, 164-178.

Marx P and Picot G (2014) Labour Market Policies and Party Preferences of Fixed-Term Workers. In Kumlin S and Stadelmann-Steffen I (eds), How Welfare States Shape the Democratic Public: Policy Feedback, Participation, Voting, and Attitudes. Cheltenham: Edward Elgar, pp. 113-131.

Rehm P (2009) Risks and Redistribution: An Individual-Level Analysis. Comparative Political Studies 42, 855-881.

Rovny AE and Rovny J (2017) Outsiders at the Ballot Box: Operationalizations and Political Consequences of Insider-Outsider Dualism. Socio-Economic Review 15, 161-185.

Rueda D (2007) Social Democracy Inside Out: Partisanship and Labour Market Policy in Industrialized Democracies. Oxford: Oxford University Press.

Schwander H and Häusermann S (2013) Who is in and Who is Out? A Risk-Based Conceptualization of Insiders and Outsiders. Journal of European Social Policy 23, 248-269.

Sverke M, Hellgren J and Näswall K (2002) No Security: A Meta-Analysis and Review of Job Insecurity and its Consequences. Journal of Occupational Health Psychology 7, 242-264.

Vlandas T (2018) The political consequences of labor market dualization: Labor market status, occupational unemployment and policy preferences. Political Science Research and Methods (in press).

Walter S (2010) Globalization and the Welfare State: Testing the Microfoundations of the Compensation Hypothesis. International Studies Quarterly 54, 403-426.

Walter S (2017) Globalization and the Demand-Side of Politics: How Globalization Shapes Labor Market Risk Perceptions and Policy Preferences. Political Science Research and Methods 5, 55-80.

Cite this article: Marx P, Picot G (2020). Three approaches to labor-market vulnerability and political preferences. Political Science Research and Methods 8, 356-361. https://doi.org/10.1017/psrm.2018.29 